\title{
Pengaruh Kepemimpinan Kepala Sekolah dan Disiplin Guru terhadap Kinerja Guru
}

\author{
Elvi Juniarti ${ }^{\bowtie 1}$, Nur Ahyani ${ }^{2}$, Arif Ardiansyah ${ }^{3}$ \\ (1) Sekolah Menengah Pertama Negeri 12 Prabumulih \\ $(2,3)$ Universitas PGRI Palembang
}

$\triangle$ Corresponding author

[juniartielvi78@gmail.com]

\begin{abstract}
Abstrak
Penelitian ini bertujuan untuk: 1) mengetahui ada atau tidak pengaruh kepemimpinan kepala sekolah terhadap kinerja guru; 2) mengetahui ada atau tidak pengaruh disiplin guru terhadap kinerja guru; 3) mengetahui ada atau tidak pengaruh kepemimpinan kepala sekolah dan disiplin guru terhadap kinerja guru. Metode penelitian yang digunakan adalah metode kuantitatif. Hasil penelitian ini menunjukkan bahwa: 1) terdapat pengaruh positif yang sangat signifikan antara gaya kepemimpinan kepala sekolah terhadap kinerja guru; 2) terdapat pengaruh positif yang sangat signifikan antara kepuasan kerja terhadap kinerja guru; 3) terdapat pengaruh positif antara komitmen organisasi dan kepuasan kerja secara bersama-sama terhadap kinerja guru.
\end{abstract}

Kata Kunci: Kepemimpinan Kepala Sekolah; Disiplin Guru; Kinerja Guru.

\begin{abstract}
This study aims to: 1) determine whether or not there is an effect of principal leadership on teacher performance; 2) knowing whether there is or not the effect of teacher discipline on teacher performance; 3) knowing whether there is an effect of principal leadership and teacher discipline on teacher performance. The research method used is a quantitative method. The results of this study indicate that: 1) there is a very significant positive effect between the principal's leadership style on teacher performance; 2 ) there is a very significant positive effect between job satisfaction on teacher performance; 3) there is a positive influence between organizational commitment and job satisfaction together on teacher performance.
\end{abstract}

\section{Keyword: Principal Leadership; Teacher Discipline; Teacher Performance}

\section{PENDAHULUAN}

Dalam implementasinya di sekolah, tujuan tersebut di atas dapat diperankan oleh kepala sekolah dalam mengelola pendidikan, baik dalam perencanaan, pengorganisasian, pelaksanaan, pengawasan, dan pengendalian pendidikan di sekolah. Kepala sekolah dituntut untuk dapat mengembangkan berbagai potensi dan kemampuannya dalam aspek kepemimpinan dalam mengelola sumber daya sekolah sesuai dengan kemampuan dan kebutuhannya. Sumber daya sekolah yang sangat penting dalam mengembangkan mutu sekolah adalah guru, dimana seorang guru memiliki tugas dan peran yang sangat besar untuk mengoptimalkan potensi yang dimiliki oleh peserta didik (Susanto, 2016).

Kepala Sekolah yang berhasil apabila mereka memahami keberadaan sekolah sebagai organisasi yang kompleks dan unik, serta mampu melaksanakan peranan kepala sekolah sebagai seseorang yang diberi tanggung jawab untuk memimpin sekolah (Wahjosumidjo, 2013). Guru merupakan salah satu faktor penentu tinggi rendahnya kualitas pendidikan. Guru merupakan agen belajar karena seorang guru dituntut sebagai fasilitator, motivator, pemacu dan pemberi inspirasi. Guru juga dapat memberikan kemudahan belajar kepada peserta didik sehingga bangkit rasa ingin tahunya dan terjadilah proses belajar yang tenang dan menyenangkan (Mulyasa, 2011).

Keberhasilan pendidikan di sekolah salah satunya ditentukan oleh motivasi kepala sekolah untuk meningkatkan kinerja dan disiplin guru dalam mengelola sistem persekolahan. Kepala sekolah sebagai pelaksanaan bertanggungjawab atas penyelenggaraan kegiatan pendidikan, administrasi sekolah, pembinaan tenaga kependidikan lainnya dan pendayagunaan serta pemeliharaan (Susanto, 2016).

Education is the most important indicator of a country's progress (Asvio et al, 2019). Education is a conscious effort to build quality human resources to compete (Tobari et al, 2018). Quality human resources are more important than the wealth of natural resources, because the wealth of natural resources cannot guarantee the welfare and success of a nation (Asvio et al, 2019). 
Tugas dan fungsi kepala sekolah tentunya tidak sedikit salah satunya adalah sebagai motivator yang kita artikan disini adalah sebagai pendorong atau penggerak yaitu bagaimana kepala sekolah dapat mendorong atau menggerakkan bawahannya tenaga pendidik dan kependidikan dalam pemenuhan tugas. Tugas tersebut tentunya dapat diselesaikan tepat pada waktunya dan dikerjakan semaksimal mungkin dalam rangka mencapai suatu keberhasilan bersama yaitu keberhasilan dalam melaksanakan visi dan misi sekolah yang telah disepakati bersama.

Keberhasilan sekolah ditentukan oleh berbagai faktor, diantaranya kepemimpinan kepala sekolah. Menurut Danim dan Suparno (2019) bahwa kepemimpinan adalah kemampuan mempengaruhi suatu kelompok ke arah pencapaian tertentu. Pengaruh itu dihasilkan dari interaksi atas dasar posisi formal ataupun informal.

Menurut Mulyasa (2011) kepala sekolah sedikitnya mempunyai peran dan fungsi sebagai Edukator, Manajer, Administrator, Supervisor, Leader, Inovator dan Motivator. Kemampuan yang harus diwujudkan kepala sekolah sebagai pimpinan dapat dianalisis dari kepribadian, pengetahuan terhadap kependidikan, visi dan misi sekolah, kemampuan mengambil keputusan, dan kemampuan berkomunikasi.

Pengaruh kepemimpinan kepala sekolah terhadap kinerja guru berupa penciptaan iklim sekolah yang dapat memacu atau menghambat efektifitas kerja guru. Sebagai pemimpin suatu instansi pendidikan, kepala sekolah harus menjadi motor penggerak bagi berjalannya proses pendidikan. Kepala sekolah selalu berupaya mencurahkan kemampuannya dalam menjalankan tugasnya untuk mencapai tujuan. Kemampuan yang harus dimiliki seorang pemimpin dalam hal ini kepala sekolah adalah memiliki kepribadian yang menjadi teladan bagi bawahannya, kemampuan memotivasi, pengambilan keputusan, komunikasi dan pendelegasian wewenang.

Pada sisi lain faktor disiplin dapat pula meningkatkan kinerja guru. Toha (2014) menyatakan disiplin kerja sebagai pelaksanaan manajemen untuk memperteguh pedoman-pedoman dipandang erat keterkaitannya dengan kinerja. Pernyataan tersebut didukung oleh pendapat Malthis dan Jackson bahwa disiplin kerja berkaitan erat dengan perilaku karyawan dan berpengaruh terhadap kinerja. Kepemimpinan kepala sekolah adalah motivator bagi kepatuhan diri pada disiplin kerja para guru. Walaupun disiplin ini hanya merupakan salah satu bagian dari ciri kinerja guru dan berkaitan dengan prosentasi kehadiran, ketidakpatuhan pada aturan, menurunnya produktivitas kerja dan apatis, tetapi ternyata hal ini membawa dampak yang sangat besar terutama pada sistem pendidikan kita yang masih memerlukan keberadaan guru secara dominan dalam proses pembelajaran. Pada tahap inilah kepemimpinan kepala sekolah dituntut untuk mampu memimpin atau mengelola sekolah, juga dituntut untuk mampu menciptakan suasana yang kondusif di lingkungan kerja sehingga dapat mencegah timbulnya desintegrasi dan mampu memberikan dorongan agar semua komponen yang ada di sekolah bersatu mencapai tujuan yang ingin dicapai.

Berdasarkan pengamatan peneliti dilapangan bahwa kepala sekolah SMP Negeri 12 Prabumulih jarang sekali berada disekolah, hal ini dikarenakan banyaknya tugas diluar sekolah seperti rapat dengan berbagai instansi yang harus dihadiri guna menentukan kemajuan sekolah harus dihadiri oleh kepala sekolah. Dengan jarangnya keberadaan kepala sekolah tersebut, tentunya dapat memberi jarak komunikasi antara kepala sekolah dengan guru. Komunikasi yang kurang dari kepala sekolah akan dapat mempengaruhi kinerja guru, karena kurangnya arahan langsung dari kepala sekolah sebagai sarana bagi guru. Dengan jarangnya kepala sekolah berada di sekolah memicu beberapa guru sering datang terlambat, tidak hadir bahkan ketika disekolahpun mereka tidak menjalankan tugasnya mengajar hanya memberikan catatat terhadap siswa. Ini salah satu faktor yang membuat gurukurang meningkatkan kinerjanya dan disiplin. Padahal keberhasilan yang dicapai guru dalam bekerja ditentukan oleh motivasi yang dimilikinya. Sedangkan untuk menjadikan sekolah agar dapat mencetak lulusan yang berkualitas diperlukan kinerja yang baik dari guru untuk dapat meningkatkan produktivitas di sekolah tersebut.

Dalam kasus pada SMP Negeri 12 Prabumulih pada saat ini masih banyak hal yang harus ditingkatkan, baik dari kinerja guru, kedisiplinansampai gaya kepemimpinan kepala sekolah. Hal ini juga diperkuat oleh penelitian terdahulu yang dilakukan oleh Rusneli dkk (2018) yang berjudul Pengaruh Kepemimpinan Kepala Sekolah, Disiplin Kerja, dan Konsep Diri terhadap Kompetensi Profesional Guru SD Negeri, berdasarkan hasil penelitiannya bahwa terdapat pengaruh kepemimpinan kepala sekolah, disiplin kerja, dan konsep diri secara bersama-sama terhadap kompetensi profesional guru guru di SDN Daerah Binaan I Kecamatan Baradatu.

Produktivitas kinerja guru akan baik, bila didukung oleh suasana iklim sekolah yang nyaman, kondusif dan kompetitif. Situasi ini mendorong guru lebih bergairah, berdisiplin dan memberikan kinerja yang baik dalam mengajar. Bila suasana iklim sekolah tidak mendukung, sepertikepemimpinan kepala sekolah bersikap acuh terhadap guru yang rajin dan yang malas, guru sering mangkir atau datang terlambat, mengurangi jam mengajar kepada siswa, hal ini akan berdampak pada pekerjaan atau kinerja guru yang menurun. Berdasarkan latar belakang di atas maka peneliti melakukan penelitian yang berjudul Pengaruh Kepemimpinan Kepala Sekolah dan Disiplin Guru terhadap Kinerja Guru di SMP Negeri 12 Prabumulih. 


\section{METODE PENELITIAN}

Metode dalam penelitian ini adalah metode kuantitatif dengan pendekatan survey. Sejalan dengan penelitian ini, menurut Sugiyono (2015) mengemukakan bahwa metode survey digunakan untuk mendapatkan data-data tempat terentu yang alamiah bukan buatan, tetapi peneliti melakukan perlakuan dalam pengumpulan data misalnya dengan mengedarkan angket/kuesioner, test, wawancara terstruktur dan sebagainya.

Populasi dalam penelitian ini ialah penelitian ini adalah seluruh guru SMP Negeri 12 Prabumulih yang berjumlah 38 orang termasuk Kepala Sekolah dan guru honorer. Teknik pengumpulan data melalui angket/kuesioner dan dokumentasi. Sebelum angket/kuesioner didistribusikan kepada responden dilakukan uji validitas dan reliabilitas terlebih dahulu.

Teknik analisis data dalam penelitian ini menggunakan teknik analisis data korelasi sederhana dan regresi berganda dengan bantuan program SPSS For Windows Versi 21. Adapun tahap pelaksanaan analisis meliputi: (1) analisis deskriptif, (2) uji persyaratan analisis: uji normalitas, uji homogenitas dan uji linearitas, dan (3) uji hipotesis.

\section{HASIL DAN PEMBAHASAN}

\section{Pengaruh Gaya Kepemimpinan Kepala Sekolah terhadap Kinerja Guru}

Hasil pengujian hipotesis pertama dapat disimpulkan bahwa terdapat pengaruh positif antara gaya kepemimpinan kepala sekolah terhadap kinerja guru. Kesimpulan tersebut menunjukkan bahwa semakin tinggi efektif gaya kepemimpinan kepala sekolah, maka akan semakin tinggi pula kinerja guru. Kuadrat koefesien korelasi anara kedua variabel sebesar 0,684. dapat diinterpretasikan bahwa bila tidak dilakukan kontrol terhadap variabel lain, maka 68,40\% proporsi variansi kinerja guru dapat dijelaskan oleh tingkat gaya kepemimpinan kepala sekolah.

Tabel 1. Hasil Uji F Regresi dengan Variabel Kinerja Guru sebagai Variabel Dependen ANOVA $^{a}$

\begin{tabular}{|ll|l|l|l|l|l|}
\hline Model & & Sum of Squares & df & Mean Square & F & Sig. \\
\hline 1 & Regression & 551,067 & 2 & 275,534 & 14,105 &, $000^{\mathrm{b}}$ \\
& Residual & 625,104 & 32 & 19,535 & & \\
& Total & 1176,171 & 34 & & & \\
\hline
\end{tabular}

a. Dependent Variable: $\mathrm{Y}$

b. Predictors: (Constant), $\mathrm{X}_{2}, \mathrm{X}_{1}$

Tabel 2. Hasil Uji t Regresi dengan Variabel Kinerja Guru sebagai Variabel Dependen Coefficients $^{\mathrm{a}}$

\begin{tabular}{|c|c|c|c|c|c|c|c|}
\hline \multirow[b]{2}{*}{ Model } & \multicolumn{2}{|c|}{ Unstandardized Coefficients } & \multirow{2}{*}{$\begin{array}{c}\begin{array}{c}\text { Standardized } \\
\text { Coefficients }\end{array} \\
\text { Beta }\end{array}$} & \multirow[b]{2}{*}{$\mathrm{t}$} & \multirow[b]{2}{*}{ Sig. } & \multicolumn{2}{|c|}{ Collinearity Statistics } \\
\hline & B & Std. Error & & & & Tolerance & VIF \\
\hline (Constant) & 13,003 & 4,595 & & 2,830 & ,008 & & \\
\hline$x 1$ & ,241 & ,143 & ,267 & 1,688 & ,101 & 663 & 1,508 \\
\hline$x 2$ & ,370 & 119 & ,494 & 3,122 & ,004 & 663 & 1,508 \\
\hline
\end{tabular}

a. Dependent Variable: $Y$

Sedangkan dari bentuk pengaruh antara gaya kepemimpinan kepala sekolah terhadap kinerja guru ditunjukkan oleh persamaan garis regresi sederhana $\hat{Y}=138,57+1,65 X 1$. Persamaan garis regresi tersebut menunjukkan kebermaknaannya yang berarti pada taraf signifikansi $5 \%$. Persamaan garis tersebut dapat diinterpretasikan bahwa perubahan satu unit skor kinerja guru akan diikuti oleh perubahan skor gaya kepemimpinan kepala sekolah sebesar 1,65 unit pada arah yang sama dengan konstanta sebesar 138,57. Gaya kepemimpinan ialah seorang pemimpin yang melakukan koordinasi dan pengawasan terhadap pekerjaan orang lain, sehingga sasaran- sasaran organisasi dapat dicapai dengan gaya dan prilaku pemimpin tersebut. Pemimpin yang baik bukanlah menyelesaikan tugas pribadinya, melainkan berupaya membantu orang lain menyelesaikan tugas-tugasnya mereka dengan baik.

Berdasarkan pengertian di atas, bahwa gaya kepemimpinan yang diterapkan oleh kepala sekolah sebagai pimpinan di sekolah harus dapat menggerakkan, mengarahkan perilaku guru untuk berbuat dan bekerja sebaik mungkin guna mencapai tujuan bersama yang telah ditetapkan, sesuai dengan gaya dan karakteristik iklim dan personal guru sebagai bawahan. Untuk dapat melaksanakan kepemimpinannya, seorang kepala sekolah dituntut mempunyai pengetahuan dan keterampilan sebagai pemimpin. Pengetahuan dan keterampilan ini dapat diperoleh melalui pengalaman belajar secara teori ataupun dari pengalamannya 
dalam praktek selama menjadi pemimpin. Dan perlunya langkah-langkah evaluasi dari setiap cara atau gaya kepemimpinan yang diterapkan, untuk mengantisipasi hal-hal yang tidak diinginkan. Keseimbangan dan kesesuaian gaya kepemimpinan yang diterapkan, akan menciptakan tujuan yang hendak dicapai. Unsur kepemimpinan kepala sekolah adalah pengaruh yang dimilikinya dan kemampuan menggunakan pengaruh tersebut serta akibat pengaruh itu bagi orang yang hendak dipengaruhi yaitu para guru, pegawai, dan warga sekolah lainnya. Pengelolaaan fungsi kepemimpinan kepala sekolah tersebut dapat memberikan pengaruh terhadap kinerja guru, dengan demikian keberhasilan tujuan pendidikan akan mudah tercapai. Maka indikator evaluasi dari gaya kepemimpinan kepala sekolah memeroleh skor tertinggi.

Korelasi antara gaya kepemimpinan kepala sekolah dengan kinerja guru yang diperoleh pada penelitian ini menunjukkan kebermaknannya, baik melalui korelasi product moment maupun korelasi parsial. Hasil analisis ini memberikan petunjuk bahwa gaya kepemimpinan kepala sekolah merupakan salah satu faktor utama yang berkonstribusi terhadap kinerja guru. Dari hasil itu pula dapat diinterpretasikan bahwa peningkatan efektivitas gaya kepemimpinan kepala sekolah akan memberikan konstribusi yang berarti terhadap kinerja guru. Hasil penelitian ini terkait pengaruh gaya kepemimpinan kepala sekolah dengan kinerja guru, telah sesuai dengan pendapat dari Sutisna (Sutanto, 2016) mengatakan bahwa peran dari kepala sekolah sebagai seorang pemimpin adalah menjadi kunci dari peningkatan atau perkembangan sekolah. Peningkatan kinerja dapat tercapai apabila kepala sekolah sebagai pemimpin mampu membimbing dan sanggup membina warga lingkungan sekolah terutama guru, sebab guru merupakan salah satu faktor penentu tinggi rendahnya mutu hasil pendidikan. Jika guru telah mendapatkan perhatian yang lebih dalam kegiatan pengajaran yang dilakukannya, maka hal itu akan meningkatkan kinerja, khususnya kinerja mengajarnya.

Hasil penelitian ini pun di dukung oleh penelitian terdahulu yang dilakukan oleh Ismarini dkk (2014) dengan judul "Pengaruh Kepemimpinan Kepala Sekolah, Disiplin Kerja dan Iklim Kerja Sekolah Terhadap Kinerja Guru SMP Negeri Kecamatan Kotabumi Kota Kabupaten Lampung Utara". Hasil penelitian memberi kesimpulan bahwa: 1) terdapat pengaruh positif dan signifikan kepemimpinan kepala sekolah dengan konstribusi sebesar 30,1\% terhadap kinerja guru SMP Negeri di Kecamatan Kotabumi Kota Kabupaten Lampung Utara, 2) terdapat pengaruh positif dan signifikan disiplin kerja dengan kontribusi sebesar 31,1\% terhadap kinerja guru SMP Negeri di Kecamatan Kotabumi Kota Kabupaten Lampung Utara, 3) terdapat pengaruh positif dan signifikan iklim kerja sekolah dengan kontribusi sebesar 33,5\% terhadap kinerja guru SMP Negeri di Kecamatan Kotabumi Kota Kabupaten Lampung Utara, 4) terdapat pengaruh kepemimpinan kepala sekolah, disiplin kerja dan iklim kerja sekolah secara bersama-sama dengan konstribusi sebesar 35,9\% terhadap kinerja guru SMP Negeri di Kecamatan Kotabumi Kota Kabupaten Lampung Utara.

\section{Pengaruh Disiplin Kerja terhadap Kinerja Guru}

Hasil pengujian hipotesis kedua dapat disimpulkan bahwa terdapat pengaruh antara disiplin kerja terhadap kinerja guru. Kesimpulan tersebut menunjukkan bahwa semakin tinggi disiplin kerja, maka akan semakin tinggi Pula kinerja guru. Kuadrat koefesoan korelasi antara kedua variabel (r2y2) sebesar 0,5069 dapat diinterpretasikan bahwa bila tidak dilakukan kontrol terhadap variabel lain, maka 50,69\% proporsi variansi kinerja guru dapat dijelaskan oleh tingkat disiplin kerja.

Sedangkan dari bentuk pengaruh antara disiplin kerja terhadap kinerja guru ditunjukkan oleh persamaan garis regresi sederhana $\hat{Y}=73,05+1,62 X 2$. Persamaan garis regresi menunjukkan kebermaknaan yang berarti pada taraf signifikansi $5 \%$. Persamaan garis regresi tersebut dapat diinterpretasikan bahwa perubahan satu unit skor kinerja guru akan diikuti oleh perubahan skor disiplin kerja sebesar 1,62 unit pada arah yang sama dengan konstanta sebesar 73,05.

Disiplin kerja merupakan suatu kondisi yang tercipta dan terbentuk melalui proses serangkaian perilaku yang menunjukkan nilai-nilai ketaatan, kepatuhan, kesetian, keteraturan dan atau ketertiban. Karena sudah menyatu dengan dirinya, sikap atau perbuatan yang dilakukannya bukan lagi atau sama sekali tidak dirasakan sebagai beban, bahkan sebaliknya akan membebani dirinya bilamana ia berbuat tidak sebagaimana lazimnya.

Dalam kaitanya dengan pekerjaan, disiplin merupakan suatu sikap dan perilaku yang menunjukkan ketaatan terhadap peraturan. Sikap disiplin akan muncul manakala bila telah muncul niat dari dalam diri guru itu sendiri, hal ini akan lebih kuat mendorong sikap dan perilaku untuk patuh dan mentaati peraturan sekolah. Sikap dan perilaku disiplin muncul ditandai oleh berbagai inisiatif, kemauan dan kehendak dalam mentaati segala peraturan yang berlaku. Sementara Kinerja guru merupakan suatu hasil yang dicapai dari apa yang telah diemban dan diamanatkan kepada guru dan dapat dipertanggungjawabkan hasilnya. Berdasarkan pendapat di atas, dapat disimpulkan bahwa kinerja adalah hasil kerja seseorang atau pegawai dalam suatu bidang pekerjaan sesuai dengan tanggung jawab yang diberikan berdasarkan standar yang telah ditetapkan sesuai dengan moral dan etika yang berlaku.

Korelasi antara disiplin kerja dengan kinerja guru yang diperoleh pada penelitian ini menunjukkan kebermaknannya, baik melalui korelasi product moment maupun korelasi parsial. Hasil analisis ini memberikan petunjuk bahwa disiplin kerja merupakan salah satu faktor utama yang berkonstribusi terhadap 
kinerja guru. Dari hasil itu pula dapat diinterpretasikan bahwa peningkatan disiplin kerja akan memberikan konstribusi yang berarti terhadap kinerja guru. Hasil penelitian ini terkait pengaruh disiplin kerja dengan kinerja guru, telah sesuai dengan pendapat dari Sutisna (Sutanto, 2016) yang mengatakan bahwa disiplin positif merupakan suatu sikap dan iklim organisasi yang setiap anggotanya mematuhi peraturan-peraturan organisasi atas kemauannya sendiri. Artinya apabila mereka patuh pada tata tertib, memahami, dan menerapkannya karena kepatuhan bukan karena takut. Apabila melanggar tata tertib organisasi artinya mereka akan memperoleh hukuman. Guru yang mempunyai disiplin kerja yang positif tentunya akan berdampak pada performa dan kinerja guru sebab keadaan tersebut berpengaruh terhadap suasana kerja. Disiplin kerja yang baik akan menciptakan suasana kerja yang kondusif. Melalui disiplin pula timbul keinginan dan kesadaran untuk menaati peraturan organisasi dan norma sosial. Namun tetap pengawasan terhadap pelaksanaan disiplin tersebut perlu dilakukan. Jadi disiplin kerja bagi guru adalah persepsi guru terhadap sikap pribadi guru dalam hal ketertiban dan keteraturan diri yang dimiliki oleh guru dalam bekerja di sekolah tanpa ada pelanggaran-pelanggaran yang merugikan dirinya.

Hasil penelitian ini pun didukung oleh penelitian yang dilakukan oleh Rifa'i (2018) dengan judul "Pengaruh Kepemimpinan Kepala Sekolah terhadap Disiplin Kerja Guru di SDN 060794 Kecamatan Medan Area. Rumusan masalah dalam penelitian ini adalah bagaimana kepemimpinan negara kepala sekolah di 060794 sekolah dasar Medan, bagaimana keadaan disiplin guru pendidikan agama Islam yang bekerja di sekolah dasar 060794 wilayah Medan, dan apakah ada pengaruh yang signifikan antara kepemimpinan Disiplin Kepala Sekolah terhadap Guru Pendidikan Agama Islam di SD Negeri 060794 Medan. Adapun tujuan dari penelitian ini adalah untuk mengetahui Status kepemimpinan kepala sekolah pada sekolah dasar 060794 Medan, untuk mengetahui keadaan disiplin kerja guru pendidikan Islam di sekolah dasar 060794 Medan, dan untuk mengetahui signifikan pengaruh antara kepemimpinan disiplin kerja kepala sekolah terhadap guru pendidikan agama Islam di SD Negeri 060794 Medan. Metode penelitian yang digunakan adalah metode kuantitatif. Instrumen penelitian menggunakan IE sekarang dan observasi. Hasil analisis menunjukkan bahwa keterampilan mengajar guru sekolah dasar di 060794 Kecamatan Medan cukup baik, hal ini ditandai dengan adanya upaya guru untuk meningkatkan kualitas pembelajaran bagi siswa, melaksanakan Sejatinya sehingga pembelajaran tujuan dapat dicapai. Berdasarkan hasil penelitian menunjukkan bahwa terdapat pengaruh yang signifikan antara kepemimpinan disiplin kerja kepala sekolah terhadap guru pendidikan agama Islam, ini dibuktikan berdasarkan perhitungan bahwa nilai yang diperoleh $r x y=0,50$ dengan kategori sedang.

\section{Pengaruh Interaksi antara Gaya Kepemimpinan Kepala Sekolah dengan Disiplin Kerja terhadap Kinerja Guru}

Hasil pengujian hipotesis ketiga dapat disimpulkan bahwa gaya kepemimpinan kepala sekolah dan disiplin kerja secara bersama-sama mempunyai pengaruh positif terhadap kinerja guru. Koefisien korelasi ganda antara kedua variabel bebas dengan variabel terikat Ry.12 sebesar 0,684. Dari koefisien korelasi tersebut, dapat dihitung koefisien determinasi (R2) sebesar 0,684 berarti bahwa $68,40 \%$ proporsi varaians kinerja guru dapat dijelaskan secara bersama-sama oleh gaya kepemimpinan kepala sekolah serta disiplin kerja.

Kinerja merefleksikan kesuksesan suatu organisasi, maka dipandang penting untuk mengukur karakteristik tenaga kerjanya. Kinerja guru merupakan kulminasi dari tiga elemen yang saling berkaitan yakni keterampilan, upaya sifat keadaan dan kondisi eksternal. Tingkat keterampilan merupakan bahan mentah yang dibawa seseorang ke tempat kerja seperti pengalaman, kemampuan, kecakapan-kecakapan antar pribadi serta kecakapan teknik. Upaya tersebut diungkap sebagai motivasi yang diperlihatkan karyawan untuk menyelesaikan tugas pekerjaannya. Sedangkan kondisi eksternal adalah tingkat sejauh mana kondisi eksternal mendukung produktivitas kerja.

Kepemimpinan di bidang pendidikan memiliki pengertian bahwa pemimpin harus memiliki keterampilan dalam mempengaruhi, mendorong, membimbing, mengarahkan dan menggerakkan orang lain yang ada hubungannya dengan pelaksanaan dan pengembangan pendidikan dan pengajaran ataupun pelatihan agar segenap kegiatan dapat berjalan secara efektif dan efisien yang pada gilirannya akan mencapai tujuan pendidikan dan pengajaran yang telah ditetapkan. Sementara disiplin kerja adalah kondisi yang tercipta dan terbentuk melalui proses serangkaian perilaku yang menunjukkan nilai-nilai ketaatan, kepatuhan, kesetian, keteraturan dan atau ketertiban. Karena sudah menyatu dengan dirinya, sikap atau perbuatan yang dilakukannya bukan lagi atau sama sekali tidak dirasakan sebagai beban, bahkan sebaliknya akan membebani dirinya bilamana ia berbuat tidak sebagaimana lazimnya. Hasil penelitian memperlihatkan kepemimpinan kepala sekolah sebagai salah satu variabel bebas penelitian memiliki hubungan yang positif dengan disiplin dan kinerja guru. Semakin tinggi kepemimpinan kepala sekolah semakin tinggi pula disiplin kerja yang berpengaruh terhdap kinerja guru, namun sebaliknya semakin rendah kepemimpinan kepala sekolah mengakibatkan disiplin dan kinerja guru menjadi rendah. 
Berdasarkan penelitian ini, dapat diartikan bahwa kinerja guru akan tinggi apabila gaya kepemimpinan kepala sekolah efektif dan jika guru memiliki disiplin kerja yang tinggi pula. Kinerja guru dapat dioptimalkan dengan gaya kepemimpinan kepala sekolah yang dapat mendorong guru untuk memiliki disiplin yang tinggi terhadap sekolah agar mereka selalu menunjukkan performa terbaik dalam mencapai tujuan sekolah. Dengan demikian temuan penelitian ini mendukung pendapat bahwa interaksi antara disiplin kerja dan gaya kepemimpinan kepala sekolah berpengaruh langsung positif terhadap kinerja guru.

Hasil penelitian ini senada dengan penelitian yang dilakukan oleh Supriadi (2017) dengan judul Pengaruh Gaya Kepemimpinan Kepala Madrasah dan Disiplin Kerja Terhadap Kinerja Guru Di Madrasah Tsanawiyah Diniyyah Putri Lampung, Kecamatan Gedong Tataan, Kabupaten Pesawaran Tahun 2016. Penelitian ini bertujuan untuk; a) Menganalisis pengaruh gaya kepemimpinan kepala madrasah terhadap kinerja guru MTs Diniyyah Putri Lampung. b) Menganalisis pengaruh disiplin guru terhadap kinerja guru MTs Diniyyah Putri Lampung. c) Menganalisis pengaruh gaya kepemimpinan kepala madrasah dan disiplin guru secara bersama-sama terhadap kinerja guru MTs Diniyyah Putri Lampung. Penelitian ini merupakan penelitian kuantitatif. Populasi penelitian adalah tenaga pendidik dan kependidikan Madrasah Tsanawiyah Diniyyah Putri Lampung yang berjumlah 55 orang. Seluruh anggota populasi menjadi sampel dalam penelitian ini total sampling Tehnik pengumpulan data menggunakan metode angket, observasi, dokumentasi. Sedangkan analisis data menggunakan analisis kuantitatif. Untuk menguji pengaruh gaya kepemimpinan kepala madrasah terhadap kinerja guru dan disiplin kerja terhadap kinerja guru digunakan regresi sederhana, sedangkan Analisis regresi berganda digunakan untuk mengukur seberapa jauh pengaruh gaya kepemimpinan kepala madrasah, sikap guru dan disiplin kerja guru terhadap kinerja guru. Hasil penelitian ini di dukung juga oleh penelitian yang dilakukan oleh Rohma et al (2020) dan Murkatik et al (2020).

\section{SIMPULAN}

Hasil penelitian ini menunjukkan bahwa: 1) terdapat pengaruh positif yang sangat signifikan antara gaya kepemimpinan kepala sekolah terhadap kinerja guru yang ditunjukkan oleh persamaan garis regresi sederhana $\hat{Y}=138,57+1,65 \times 1$. Ini berarti, bahwa, peningkatan efektivitas gaya kepemimpinan kepala madrasah akan mengakibatkan meningkatnya kinerja guru. 2) terdapat terdapat pengaruh positif yang sangat signifikan antara kepuasan kerja terhadap kinerja guru yang ditunjukkan oleh persamaan garis regresi sederhana $\hat{Y}=73,05+1,62 X 2$. dengan konstanta sebesar 73,05. Ini berarti, peningkatan disiplin kerja guru akan mengakibatkan meningkatnya kinerja guru. 3) terdapat pengaruh positif antara komitmen organisasi dan kepuasan kerja secara bersama-sama terhadap kinerja guru yang ditunjukkan oleh koefisien korelasi ganda antara kedua variabel bebas dengan variabel terikat Ry.12 sebesar 0,833. Ini berarti, bila terjadi kenaikan pada efektivitas gaya kepemimpinan kepala madrasah dan dilakukan kontrol terhadap disiplin kerja guru, maka kenaikan tersebut akan diikuti oleh kenaikan pada kinerja guru

\section{UCAPAN TERIMA KASIH}

Penulis mengucapkan terima kasih diberikan kepada semua pihak yang membantu penulisan dan penerbitan jurnal ini sehingga artikel ini dapat dipublikasikan.

\section{DAFTAR PUSTAKA}

Asvio, N., Yamin, M., \& Risnita. (2019). Influence of Leadership Style, Emotional Intelligence and Job Satisfaction toward Organizational Commitment (Survey at SMA Muhammadiyah South Sumatera). International Journal of Scientific \& Technology Research 8 (8).

Danim, S., \& Suparno. (2019). Manajemen dan Kepemimpinan Transformasional Kekepalasekolahan. Jakarta: Rineka Cipta.

Ismarini, E., Djasmi, S., \& Suntoro, I. (2014). Pengaruh Kepemimpinan Kepala Sekolah, Disiplin Kerja dan Iklim Kerja Sekolah terhadap Kinerja Guru SMP Negeri Kecamatan Kotabumi Kota Kabupaten Lampung Utara. Jurnal Manajemen Mutu Pendidikan 2 (1).

Mulyasa, E. (2011). Menjadi Kepala Sekolah Yang Profesional. Bandung: PT Remaja Rosdakarya.

Murkatik, K., Harapan, E., \& Wardiah, D. (2020). The Influence of Professional and Pedagogic Competence on Teacher's Performance. Journal of Social Work and Science Education, 1(1), 58-69. Retrieved from https://ejournal.karinosseff.org/index.php/jswse/article/view/10.

Rifa'i, M. (2018). Pengaruh Kepemimpinan Kepala Sekolah terhadap Disiplin Kerja Guru di SD Negeri 060794 Kecamatan Medan Area. HIJRI- Jurnal Manajemen Pendidikan dan Keislaman, 7 (1).

Rohma, S., Harapan, E., \& Wardiah, D. (2020). The Influence of School-Based Management and Teacher's Professionalism toward Teacher's Performance. Journal of Social Work and Science Education, 1(1), 13-23. Retrieved from https://ejournal.karinosseff.org/index.php/jswse/article/view/6 
Rusneli., Sumadi., \& Karwan, H. (2018). Pengaruh Kepemimpinan Kepala Sekolah, Disiplin Kerja, dan Konsep Diri Terhadap Kompetensi Profesional Guru SD Negeri. Jurnal Manajemen Mutu Pendidikan FKIP Unila 6 (1).

Sugiyono. (2015). Metode Penelitian Pendidikan, Pendekatan Kuantitatif, Kualitatif dan R \& D. Bandung: Alfabeta.

Supriadi. (2017). Pengaruh Gaya Kepemimpinan Kepala Madrasah dan Disiplin Kerja terhadap Kinerja Guru di Madrasah Tsanawiyah Diniyyah Putri Lampung, Kecamatan Gedong Tataan, Kabupaten Pesawaran. UIN Raden Intan Lampung: Tesis.

Sutanto, A. (2016). Manajemen Peningkatan Kinerja Guru Konsep, Strategi, dan Implementasi. Jakarta: Kencana.

Tobari., Kristiawan, M. \& Asvio, N. (2018). The Strategy of Headmaster on Upgrading Educational Quality in Asean Economic Community (AEC) Era. International Journal of Scientific \& Technology Research 7 (4).

Toha, M. (2014). Kepemimpinan dalam Manajemen. Jakarta: PT Raja Grapindo.

Wahjosumidjo. (2013). Kepemimpinan Kepala Sekolah (Tinjauan Teoritik dan Permasalahannya). Jakarta: Rajawali Press. 